\title{
Metallurgy and materials Influence of carbon content on the microstructure formation of duplex stainless steels Fe-25Cr-5Ni \\ http://dx.doi.org/10.1590/0370-44672021740011
}

\section{Emanuelle Machado Amaral ${ }^{1,3}$ \\ http://orcid.org/0000-0002-8252-286X \\ Katia Cristiane Gandolpho Candioto ${ }^{2,4}$ \\ https://orcid.org/0000-0001-8600-5467 \\ Angelo Fernando Padilha ${ }^{1,5}$ \\ https://orcid.org/0000-0002-5494-9137}

${ }^{1}$ Universidade de São Paulo - USP,

Escola Politécnica - EP, Departamento de

Engenharia Metalúrgica e de Materiais,

São Paulo - São Paulo - Brasil.

${ }^{2}$ Universidade de São Paulo - USP,

Escola de Engenharia de Lorena - EEL,

Departamento de Engenharia de Materiais,

Lorena - São Paulo - Brasil.

E-mails: ${ }^{3}$ emanuelleamaral@usp.br,

${ }^{4}$ kcandioto@usp.br, ${ }^{5}$ padilha@usp.br

\begin{abstract}
This study evaluated the as-cast microstructure of three alloys based on Fe-25\%Cr-5\%Ni weight (wt.) composition whose carbon content is $0.02 \mathrm{wt} . \%, 0.12 \mathrm{wt} . \%$, and 0.37 wt. $\%$, respectively. Thermocalc was applied to predict the possible phases that could be formed during the cooling of each alloy and then the cross-sections of the ingots were characterized. The first alloy, with $0.02 \mathrm{wt} . \% \mathrm{C}$, presented a microstructure composed of ferrite and austenite, which was formed through solid-state precipitation. The second alloy, with $0.12 \mathrm{wt} . \% \mathrm{C}$, showed a microstructure formed by ferrite, austenite from the peritectic reaction $(L+\delta \rightarrow \gamma)$ and $\mathrm{M}_{23} \mathrm{C}_{6}(\mathrm{M}=\mathrm{Fe}, \mathrm{Cr})$ carbide. Finally, the third alloy, with $0.37 \mathrm{wt} . \% \mathrm{C}$, exhibited a microstructure formed by dendrites of ferrite and austenite, also formed according to the peritectic reaction $(L+\delta \rightarrow \gamma)$, with an $\mathrm{M}_{23} \mathrm{C}_{6}(\mathrm{M}=\mathrm{Fe}, \mathrm{Cr})$ and $\mathrm{M}_{7} \mathrm{C}_{3}(\mathrm{M}=\mathrm{Fe}, \mathrm{Cr})$ carbide network in the interdendritic regions.
\end{abstract}

Keywords: duplex stainless steels, high carbon, thermocalc, microstructure.

\section{Introduction}

Duplex stainless steels can be classified according to their carbon content into two groups: low carbon duplex stainless steels and high carbon duplex stainless steels. The first one contains up to $0.08 \mathrm{wt} . \%$ of carbon and corresponds to a majority of the world production, while the second, whose carbon content is in the range of $0.3-0.5 \mathrm{wt} . \%$, are still little studied. Among the high carbon duplex stainless steels, it is possible to mention some mass compositions of the German standard, such as those of material number $1.4464 \mathrm{C}=0.3-0.5 \%$; $\mathrm{Cr}=26.0-28.0 \% ; \mathrm{Ni}=4.0-6.0 \%$; $\mathrm{Mo}=2.0-2.5 \%$ ) (Werkstoffnummer, W. Nr), and $1.4822(\mathrm{C}=0.3-0.5 \%$; $\mathrm{Cr}=23.0-25.0 \% ; \mathrm{Ni}=3.5-5.5 \%$ ) (Padilha and Plaut, 2013).

The high carbon duplex stainless steels represent a market niche of German foundries, being employed in the manufacture of cast components like centrifuges and pump housings for the mining industry and the chemical sector (Arnold et al., 2004). As reported by the work of Pohl and Ibach (1994), the use of this group of duplex stainless steel can be justified due to the formation of a carbide network in its microstructure, which leads to more resistance to wear compared to those with low carbon content, like $1.4462(\mathrm{C} \leq 0.03 \%$; $\mathrm{Cr}=21.0-23.0 \%$; $\mathrm{Ni}=4.5-6.5 \% ; \mathrm{Mo}=2.5-3.5 \%)$.

According to Fig. 1, which illustrates the pseudo-binary $\mathrm{Cr}-\mathrm{Ni}$ phase diagram resultant of a cut in the ternary system $\mathrm{Fe}-\mathrm{Cr}-\mathrm{Ni}$, there are four solidification ways for stainless steels: A - austenitic $(L \rightarrow L+\gamma \rightarrow \gamma)$; AF - austenitic-ferritic $(L \rightarrow L+\gamma \rightarrow L+\gamma+\delta \rightarrow \gamma+\delta)$; FA-ferriticaustenitic $(L \rightarrow L+\delta \rightarrow L+\delta+\gamma \rightarrow \delta+\gamma)$ and $\mathrm{F}-$ ferritic $(L \rightarrow L+\delta \rightarrow \delta$ ) (Fu et al., 2008; Padilha and Plaut, 2013). The duplex stainless steels with low carbon content present a ferritic solidification mode and austenite is formed through solid-state precipitation. On the other hand, the high carbon duplex stainless steels have a ferritic-austenitic solidification mode, with ferrite also being the first phase to solidify, and then the remaining liquid - rich in austenitizing elements - solidifies to form austenite and $\mathrm{M}_{23} \mathrm{C}_{6}(\mathrm{M}=\mathrm{Fe}, \mathrm{Cr})$ carbide, which is the most common carbide found in duplex stainless steels (Padilha and Plaut, 2013; Knyazeva and Pohl, 2013). The $\mathrm{M}_{7} \mathrm{C}_{3}(\mathrm{M}=\mathrm{Fe}, \mathrm{Cr})$ carbide is usually observed in high-chromium white cast irons. However, it can be also detected after solidification of the heat-resistant austenitic stainless steel with mass-based composition $\mathrm{Fe}-0.4 \% \mathrm{C}-25 \% \mathrm{Cr}-20 \% \mathrm{Ni}$ (Wieczerzak et al., 2017; Padilha and Rios, 2002). 


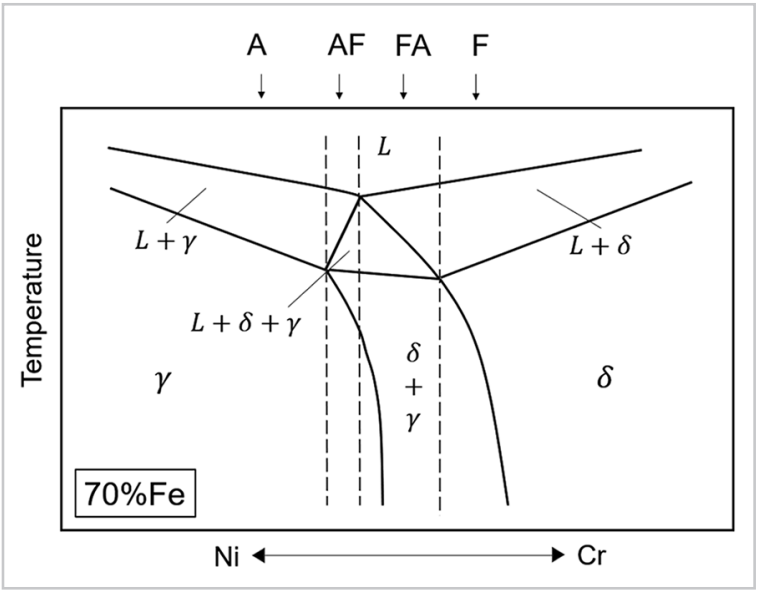

Figure 1: Solidification modes of stainless steels with 70 wt.\%Fe represented in the pseudo-binary

Cr-Ni phase diagram. A) $L \rightarrow L+\gamma \rightarrow \gamma$; AF) $L \rightarrow L+\gamma \rightarrow L+\gamma+\delta \rightarrow \gamma+\delta$; FA) $L \rightarrow L+\delta \rightarrow L+\delta+\gamma \rightarrow \delta+\gamma$ and F) $L \rightarrow L+\delta \rightarrow \delta$. Adapted from Fu et al. (2008).

It is worth mentioning that although there are several published works on low carbon duplex stainless steels, such as the book of Robert Gunn (2003) and recently the articles of Li et al. (2019) and Guo et al. (2021), there is still a lack of publications that mention the high carbon ones. It draws the attention of the reader that even fundamental aspects of the high carbon duplex steels, like its microstructure evolution during solidification, are not well-known. Accordingly, the present research aims to study the microstructure formation of three mass-based $\mathrm{Fe}-25 \% \mathrm{Cr}-5 \% \mathrm{Ni}$ alloys whose carbon contents is $0.02 \mathrm{wt} . \%, 0.12 \mathrm{wt} . \%$, and 0.37 wt. $\%$, respectively.

\section{Materials and experimental procedure}

The alloys studied in this research, designed by the numbers 1,2 , and 3 according to their carbon content, were melted using a cast-iron mold in a vacuum induction furnace and cooled to room temperature, aiming the weight-based composition Fe-
$25 \% \mathrm{Cr}-5 \% \mathrm{Ni}$. Table 1 shows the chemical composition of each alloy provided by the Dorrënberg Edelstahl company.

Table 1 - Chemical composition (wt.\%) of the alloys 1, 2 and 3.

\begin{tabular}{c|c|c|c|c|c|c|c|c|c|c|c}
\hline Alloy & $\mathrm{C}$ & $\mathrm{Fe}$ & $\mathrm{Cr}$ & $\mathrm{Ni}$ & $\mathrm{Mn}$ & $\mathrm{Si}$ & $\mathrm{N}$ & $\mathrm{P}$ & $\mathrm{S}$ & $\mathrm{Mo}$ & $\mathrm{Ti}+\mathrm{Nb}$ \\
\hline 1 & 0.02 & 67.09 & 25.62 & 5.67 & 0.82 & 0.64 & 0.03 & 0.01 & 0.02 & 0.01 & 0.07 \\
\hline 2 & 0.12 & 70.35 & 23.47 & 4.83 & 0.46 & 0.64 & 0.01 & 0.01 & 0.02 & 0.01 & 0.08 \\
\hline 3 & 0.37 & 66.92 & 25.75 & 5.13 & 0.98 & 0.71 & 0.03 & 0.01 & 0.02 & 0.01 & 0.07 \\
\hline
\end{tabular}

The first experimental part of this study consisted of determining the possible phases that could be formed during the solidification of each alloy based on its chemical composition, assuming the condition of thermodynamic equilibrium. To this extent, Thermocalc software and the TCFE 8 thermodynamic database were used.
Next, the ingots (alloys 1, 2, and 3) were cut in half by water-jet due to its low degree of heating. The region selected to be analyzed by microstructural characterization techniques was cut using the Isomet machine model Buehler 5000 with diamond disc and water-based coolant. Fig. 2 illustrates schematically the cuts made in the ingots of the alloys 1,2, and 3 . The blue-colored area was analyzed by optical microscopy $(\mathrm{OM})$ and chemical microanalysis of selected regions using dispersive energy X-ray spectrometry (EDS) coupled with scanning electron microscope (SEM) model FEG Inspect 50 and X-ray diffraction (XRD).

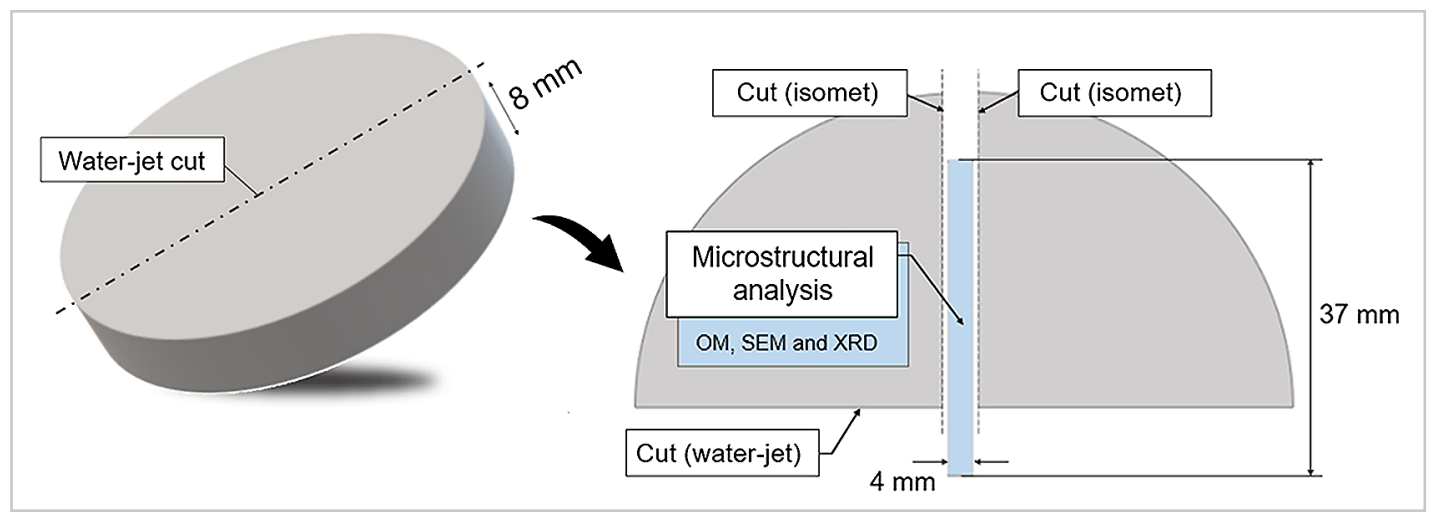

Figure 2 - Schematic representation of the cuts made in the ingots of the

alloys 1, 2, and 3. The blue-colored area was analyzed using microstructural characterization techniques. 
The metallographic sample preparation consisted of grinding, polishing with diamond suspension of 6,3 , and $1 \mu \mathrm{m}$ and etching. The Marble's reagent $(20 \mathrm{~mL}$ of distilled water, $20 \mathrm{~mL}$ of $\mathrm{HCl}$, and $4 \mathrm{~g}$ of $\mathrm{CuSO}_{4}$ ) was used to reveal the macrostructures and modified $\mathrm{Be}$ -

\section{Results and discussion}

In this section, the symbol $\gamma$ was used to designate austenite formed directly from the solidification of the

molten metal; $\gamma_{2}$ to represent austenite resultant from precipitation in solid-state $\left(\delta \rightarrow \gamma_{2}\right)$, and $\gamma_{3}$ to represent $10^{\circ}$ to $110^{\circ}$, and angular pitch of $0.02^{\circ}$. Later, an additional XRD analysis was performed on alloy 3 , however, with an angular pitch of $0.01^{\circ}$ and from $40^{\circ}$ to $55^{\circ}$. More details about the experimental procedure are described in the thesis of Amaral (2021).

austenite formed from the eutectoid decomposition of ferrite.

and 2, in alloy 3 the $\mathrm{M}_{7} \mathrm{C}_{3}(\mathrm{M}=\mathrm{Fe}, \mathrm{Cr})$ eutectic is formed before the $\mathrm{M}_{23} \mathrm{C}_{6}$ ( $\mathrm{M}=\mathrm{Fe}, \mathrm{Cr})$ carbide. cooling under equilibrium conditions. It

can be seen that the increase in carbon content promotes carbide formation and, as a result, in contrast to alloys 1
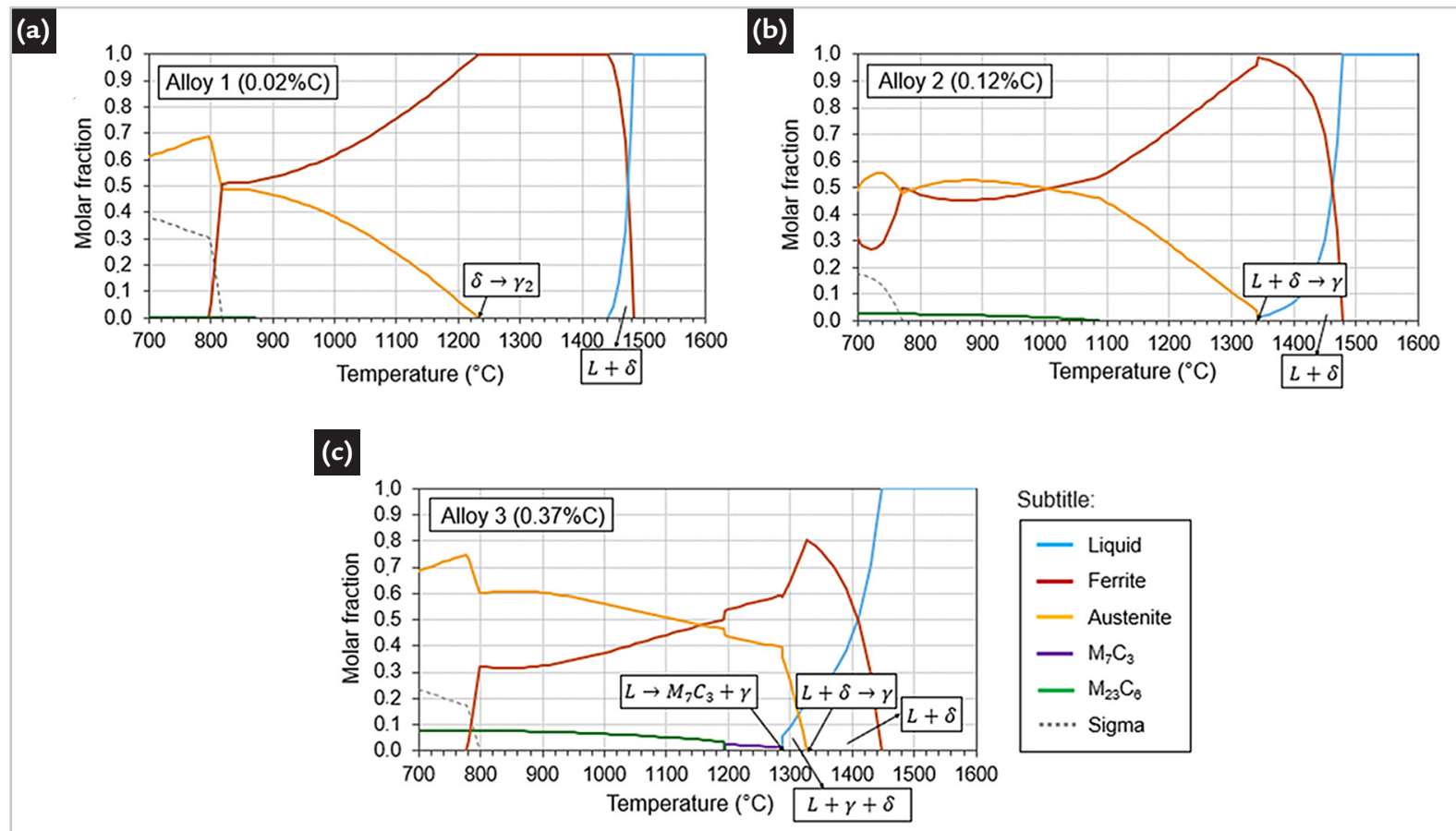

Figure 3 - Predicted phases for the alloys (a) 1, (b) 2, and (c) 3 during cooling under equilibrium conditions.

Table 2 describes the phases shown in Fig. 3 with their respective formation temperatures. In alloy 1 , austenite is formed through precipitation in solid-state, while in alloys 2 and 3 , it follows the peritectic reaction $(L+\delta \rightarrow \gamma)$. The $\mathrm{M}_{23} \mathrm{C}_{6}$ carbide growth, as well as sigma phase $(\sigma)$ in duplex stainless steels, take place according to the transformations $\left(\delta \rightarrow M_{23} C_{6}+\gamma_{3}\right)$ and $\left(\delta \rightarrow \sigma+\gamma_{3}\right)$ respectively, consuming ferrite in the microstructure (Ohmori and Maehara, 1984; Knyazeva and Pohl, 2013; Padilha and Plaut, 2013).

Table 2 - Formation temperatures of the phases predicted in alloys 1, 2, and 3.

\begin{tabular}{c|c|c|c}
\hline Phase & Alloy $\mathbf{1}(\mathbf{0 . 0 2} \% \mathrm{C})$ & Alloy 2 (0.12\%C) & Alloy 3 (0.37\%C) \\
\hline Ferrite & $1484^{\circ} \mathrm{C}$ & $1478^{\circ} \mathrm{C}$ & $1447^{\circ} \mathrm{C}$ \\
\hline Austenite & $1233^{\circ} \mathrm{C}\left(\delta \rightarrow \gamma_{2}\right)$ & $1344^{\circ} \mathrm{C}(L+\delta \rightarrow \gamma)$ & $1327^{\circ} \mathrm{C}(L+\delta \rightarrow \gamma)$ \\
\hline $\mathrm{M}_{7} C_{3}$ carbide & - & - & $1287^{\circ} \mathrm{C}\left(L \rightarrow M_{7} C_{3}+\gamma\right)$ \\
\hline $\mathrm{M}_{23} \mathrm{C}_{6}$ carbide & $870^{\circ} \mathrm{C}\left(\delta \rightarrow M_{23} C_{6}+\gamma_{3}\right)$ & $1087^{\circ} \mathrm{C}\left(\delta \rightarrow M_{23} C_{6}+\gamma_{3}\right)$ & $1193^{\circ} \mathrm{C}\left(M_{7} C_{3} \rightarrow M_{23} C_{6}\right)$ \\
\hline Sigma & $818^{\circ} \mathrm{C}\left(\delta \rightarrow \sigma+\gamma_{3}\right)$ & $770^{\circ} \mathrm{C}\left(\delta \rightarrow \sigma+\gamma_{3}\right)$ & $798^{\circ} \mathrm{C}\left(\delta \rightarrow \sigma+\gamma_{3}\right)$ \\
\hline \multicolumn{4}{|r}{}
\end{tabular}




\subsection{Characterization of alloys 1, 2 and 3}

It should be mentioned that not all phases predicted in item 3.1 will be present in the final microstructure of the three alloys, since most phase transformations in duplex stainless steels are time-temperature dependent, and in Fig.3, the time necessary for their formation was not considered.

Fig. 4 (a) and (b) shows the as-cast macrostructure and microstructure obtained for alloy 1 , which presented the ferritic solidification mode $(L \rightarrow \delta+L \rightarrow \delta)$. Austenite was formed through solid-state precipitation $\left(\delta \rightarrow \gamma_{2}\right)$ and three different morphologies can be observed according to the classification proposed by Dubé (1958) and later extended by Aaronson
(1962), which is still used in recent articles (Li et al., 2019), for pro eutectoid ferrite in steels: intergranular; Widmanstätten plates; and intragranular. The presence of $\mathrm{M}_{23} \mathrm{C}_{6}(\mathrm{M}=\mathrm{Fe}, \mathrm{Cr})$ carbide and sigma phase could not be observed, since solidification did not occur under equilibrium conditions.

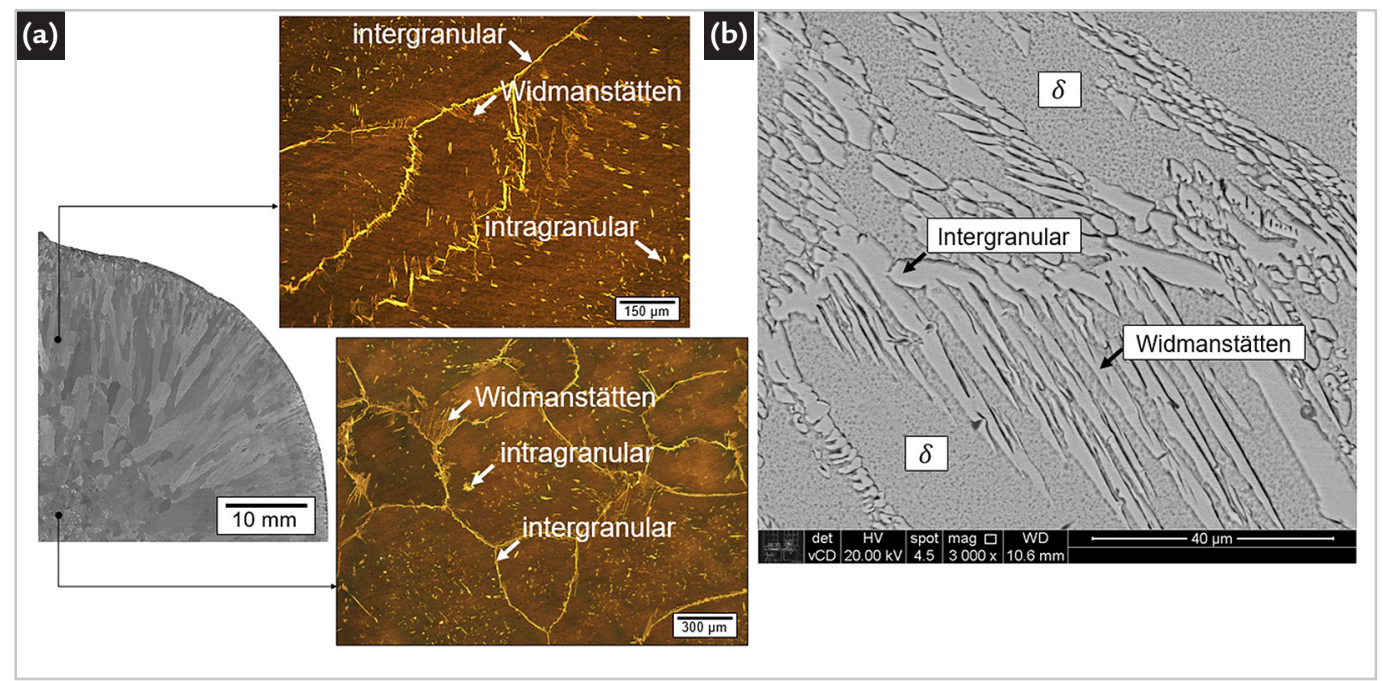

Figure 4 - (a) As-cast microstructure of the alloy 1 (0.02 wt.\%C) and (b) SEM/BSE image of Widmanstätten austenite.

Fig. 5 (a) exhibits the macrostructure and microstructure obtained for alloy 2 . According to its microstructure formation sequence predicted in Fig. 3, austenite nucleation occurs through the peritectic reaction $(L+\delta \rightarrow \gamma)$. Since solidification occurred out of equilibrium conditions, the peritectic transformation $(\delta \rightarrow \gamma)$ did not go to completion and the resultant microstructure of alloy 2 is mainly formed by ferrite and austenite, apart from the presence of carbides. According to Knyazeva and Pohl (2013) carbon has a strong affinity to grain boundaries, which leads to carbide precipitation on the ferritic-austenitic interphase. Fig. 5 (b) is an SEM/BSE image of the carbides formed in alloy 2. Their fraction in the microstructure, estimated by quantitative stereology, is around $1.4 \pm 0.5 \%$.
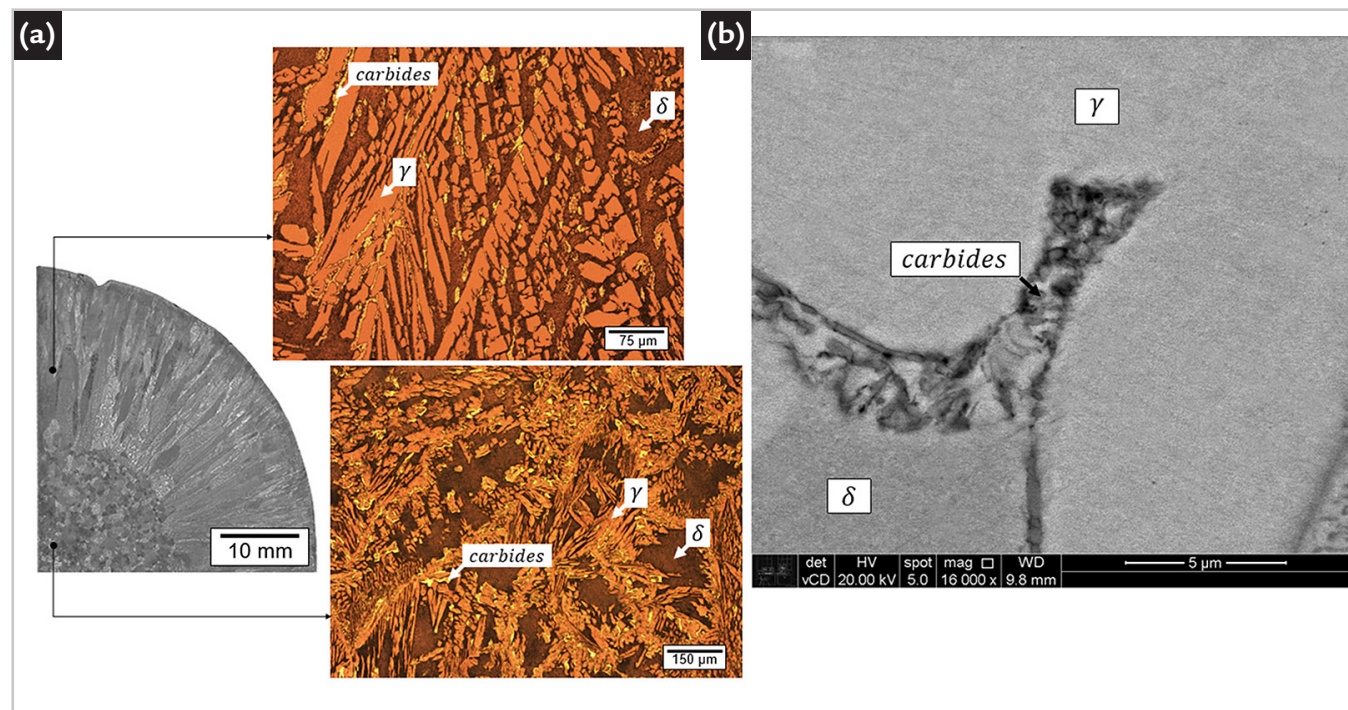

Figure 5 - (a) As-cast microstructure of the alloy 2 (0.12 wt.\%C) and

(b) SEM/BSE image of the carbides formed between ferrite and austenite.

The results of chemical microanalysis in selected regions, shown in Fig. 6, indicated that carbide is the richest phase in chromium, followed by ferrite and austenite. However, it is important to mention that the electron beam may also interact with other adjacent regions in addition to the one to be analyzed due to its small size, especially in the case of carbides. 

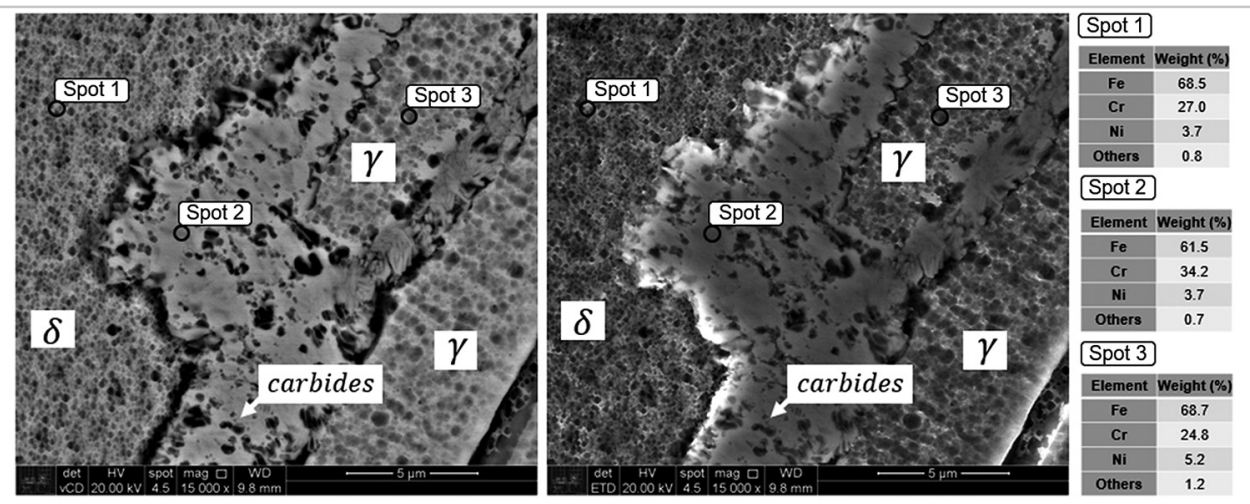

Figure 6 - Chemical microanalysis in selected regions of alloy $2(0.12 \% \mathrm{C})$. (a) SEM/BSE and (b) SEM/SE images. Others: Mn, Cu, and Si.

According to Fig. 7, alloy 3 does not have an as-cast structure that can be observed on a macroscopic scale, but a microstructure formed by den- drites of austenite and ferrite with an extensive network of carbides in the interdendritic regions, which can be observed in details by SEM. The overall fraction of carbides estimated in the microstructure by quantitative stereology is $3.67 \pm 1.3 \%$.

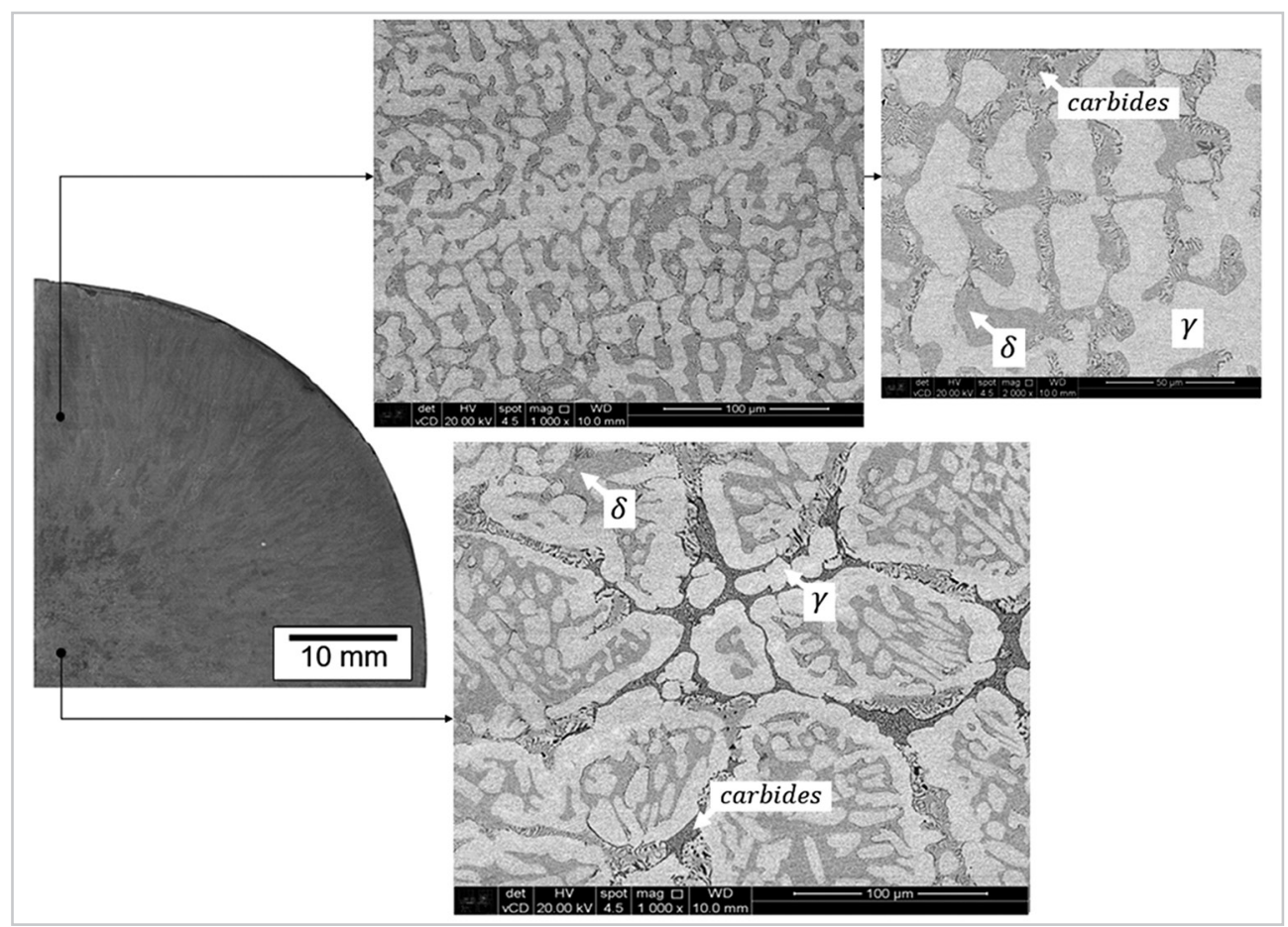

Figure 7 - As-cast structure of the alloy $3(0.37 \% \mathrm{C})$ with the micrographs of the columnar and equiaxial regions made by SEM/BSE.

The results of the quantitative chemical microanalysis in selected points of the microstructure in alloy 3 indicated differences between the composition of the carbides located in the center of the ingot $(65.8 \mathrm{wt} . \%$ of chromium) and the composition of those located in the region whose microstructure is formed by columnar dendrites (31.6 wt.\% of chromium).
As shown in Fig. 8 (a) and (b), the carbides located in the center of the ingot of alloy 3 are richer in chromium compared to those located outside the central region. 


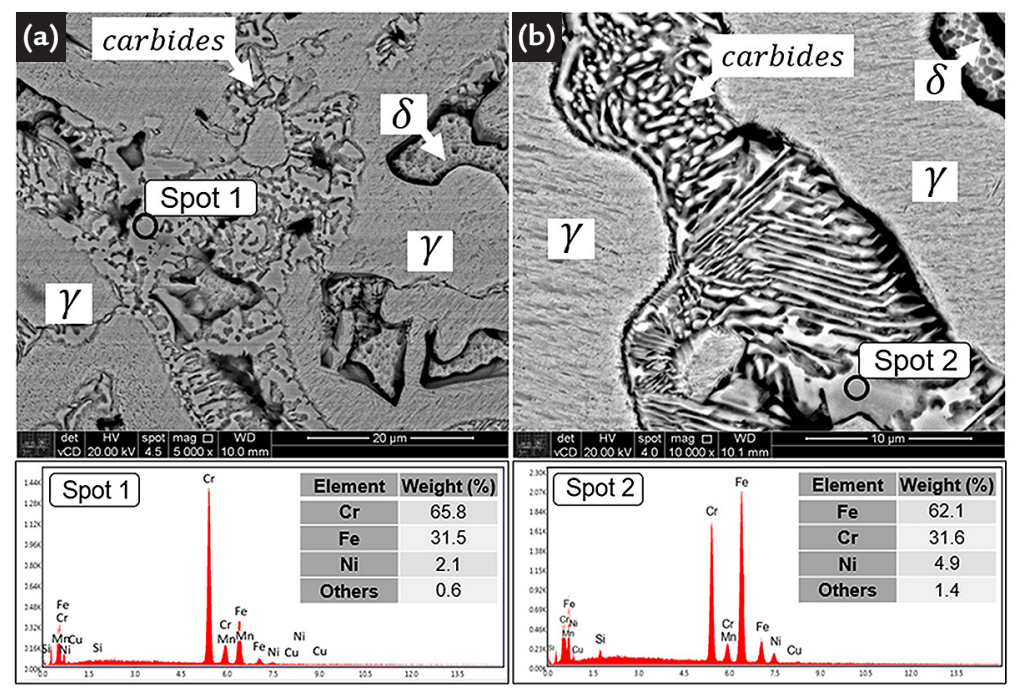

Figure 8 - Chemical microanalysis of the carbides located

(a) in the central region and (b) outside the central region of the ingot of the alloy 3. Others: $\mathrm{Mn}, \mathrm{Cu}$, and $\mathrm{Si}$.

Kliauga (1991) found similar chromium contents in $\mathrm{M}_{7} \mathrm{C}_{3}$ carbides present in the mass-based $\mathrm{Fe}$ $26.31 \% \mathrm{Cr}-2.96 \% \mathrm{C}-0.97 \% \mathrm{Mn}$ alloy.
Table 3 shows the chemical composition estimated for the $\mathrm{M}_{7} \mathrm{C}_{3}$ carbide according to Kliauga's research and those found in the center of the ingot of alloy 3 . The results strongly suggest that the carbide with higher chromium content found in the center of the ingot of alloy 3 corresponds to $\mathrm{M}_{7} \mathrm{C}_{3}$.

Table 3 - Approximate chemical composition (wt.\%) of $\mathrm{M}_{7} \mathrm{C}_{3}$ carbides found in literature and that observed in alloy 3.

\begin{tabular}{c|c|c|c|c}
\hline Source & $\mathbf{C r}$ & $\mathbf{M n}$ & $\mathbf{F e}$ & $\left(\mathrm{Cr}_{\mathrm{x}} \mathrm{Fe}_{\mathrm{\gamma}}\right) \mathrm{C}_{3}$ \\
\hline Kliauga (1991) & $69.4 \%$ & $1.1 \%$ & $29.4 \%$ & $\left(\mathrm{Cr}_{5.1} \mathrm{Fe}_{1.9}\right) \mathrm{C}_{3}$ \\
\hline Present authors & $65.8 \%$ & $0.1 \%$ & $31.5 \%$ & $\left(\mathrm{Cr}_{4.8} \mathrm{Fe}_{2.2}\right) \mathrm{C}_{3}$ \\
\hline
\end{tabular}

Fig. 9 shows the XRD results obtained for alloys (a) 1, (b) 2 , and (c) 3. In the first alloy's diffraction pattern, only peaks compatible with ferrite and austenite were found. However, in the diffraction pattern of alloy 2, apart from austenite and ferrite peaks, three low-intensity peaks compat- ible with those of the $\mathrm{M}_{23} \mathrm{C}_{6}$ carbide were found close to the positions $2 \theta=28^{\circ}, 38^{\circ}$, and $48^{\circ}$, which proves that this is the carbide observed in the material's microstructure. In the diffraction pattern of alloy 3 , in addition to the $\mathrm{M}_{23} \mathrm{C}_{6}$ carbide peaks, the peak close to the angle $2 \theta=46^{\circ}$, indicated by the lilac-colored arrow, is characteristic of the $\mathrm{M}_{7} \mathrm{C}_{3}$ carbide, which confirms the presence of both types of carbides in the microstructure of the third alloy. The low intensity of the carbide peaks in the diffractograms can be justified due to its low volume fraction.
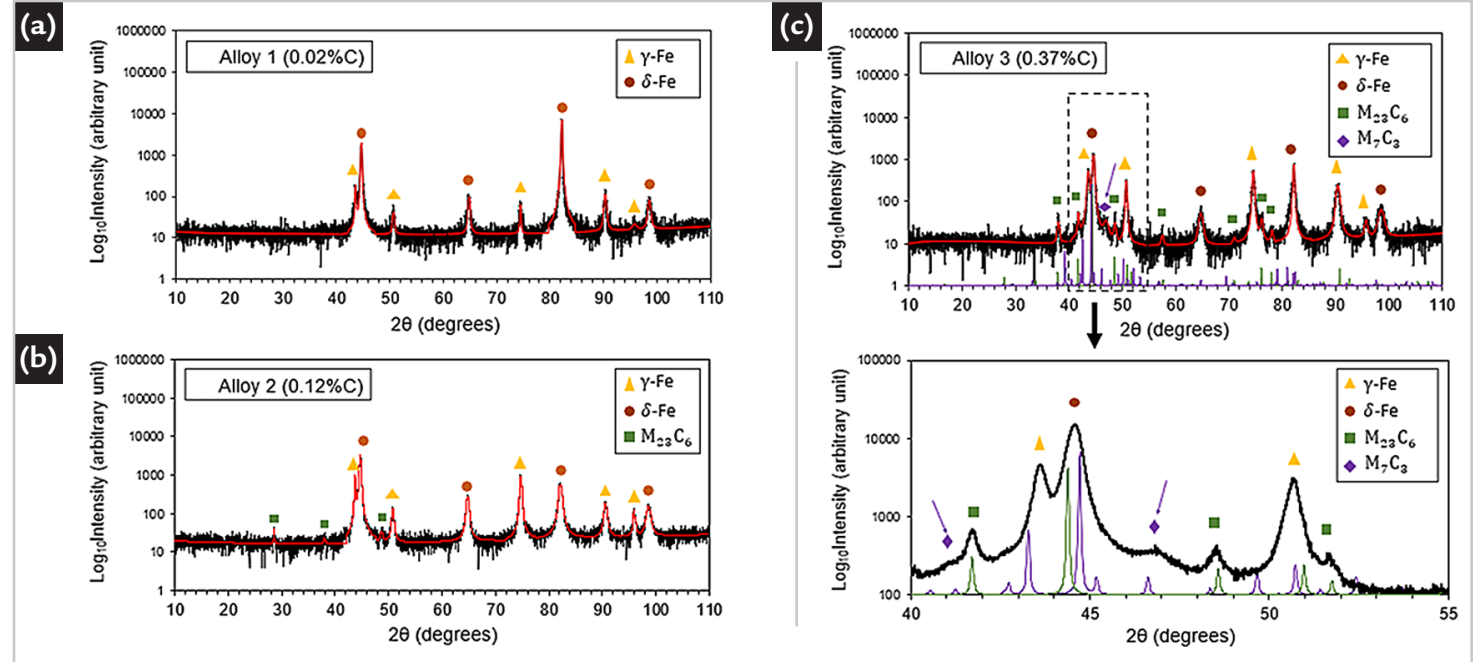

Figure 9 - Diffraction patterns obtained for alloys (a) 1, (b) 2, and (c) 3.

Considering that the center of the ingot is the last region to solidify and that during solidification the carbon content in the liquid is higher than in the solid, it is estimated that most of the $\mathrm{M}_{7} \mathrm{C}_{3}(\mathrm{M}=\mathrm{Fe}, \mathrm{Cr})$ carbides are concentrated in that area. However, the possibility of such carbides be- ing in the other regions of the ingot cannot be ruled out. Thus, the microstructure of the alloy 3 is composed of ferrite, austenite and by a network of 
$\mathrm{M}_{7} \mathrm{C}_{3}(\mathrm{M}=\mathrm{Fe}, \mathrm{Cr})$ and $\mathrm{M}_{23} \mathrm{C}_{6}(\mathrm{M}=\mathrm{Fe}$, $\mathrm{Cr})$ carbides, taking into account that those of the $\mathrm{M}_{7} \mathrm{C}_{3}$ type are formed in the regions where the $\mathrm{C}: \mathrm{M}$ ratio is higher.

\subsection{Schematic representation of the alloys 1, 2, and 3 microstructure formation}

Based on the results obtained for the three alloys analyzed in this study, to explain their stages of microstructure formation, schematic drawings were proposed. Fig. 10 shows the position of the alloys 1, 2, and 3 in the section of the mass-based Fe-25\%Cr-5\% Ni-0.80\% Mn$0.65 \% \mathrm{Si}-0.03 \% \mathrm{~N}$ phase diagram and the schematic representations of each alloy's microstructure evolution.

Alloy 1 presented ferritic solidification mode $(L \rightarrow L+\delta \rightarrow \delta)$ with austenite formed by solid-state precipitation $\left(\delta \rightarrow \gamma_{2}\right)$. Its microstructure formation path can be described as: at the point a) there is only liquid; at the point b) liquid and ferrite; at the point c) ferritic grains and at the point $\mathrm{d}$ ) austenite precipitation is represented.

In contrast to alloy 1 , alloy 2 presented the solidification sequence $(L \rightarrow L+\delta \rightarrow \delta+\gamma)$. According to its microstructure formation path at the point a) there is only liquid; at b) liquid and ferrite; at c) austenite is formed according to the peritectic reaction $(L+\delta \rightarrow \gamma)$ between liquid and ferrite and at point $\mathrm{d}$ ), located in the $\delta+\gamma$ field, while the peritectic transformation $\delta \rightarrow \gamma$ continues in the solid-state. A fifth stage e) was added to represent $\mathrm{M}_{23} \mathrm{C}_{6}$ carbide precipitation.

On the other hand, alloy 3 showed the solidification sequence $\left(L \rightarrow L+\delta \rightarrow \delta+\gamma+L \rightarrow \delta+\gamma+M_{7} C_{3}\right)$.
According to its microstructure formation, the path proposed is the following: at point a) there is only liquid; at point b) ferrite and liquid, which becomes rich in austenitizing elements; at point c) austenite were formed according to the peritectic reaction between ferrite and liquid, and it tends to grow during peritectic transformation consuming both phases; at point $\mathrm{d}$ ) the formation of the $\mathrm{M}_{7} \mathrm{C}_{3}$ carbide occurs according to the eutectic reaction $\left(L \rightarrow \gamma+M_{7} C_{3}\right)$ from the liquid and as cooling proceeds, precipitation of the $\mathrm{M}_{23} \mathrm{C}_{6}$ carbide occurs, preferably at the interface between ferrite and austenite, which is represented as stage e).

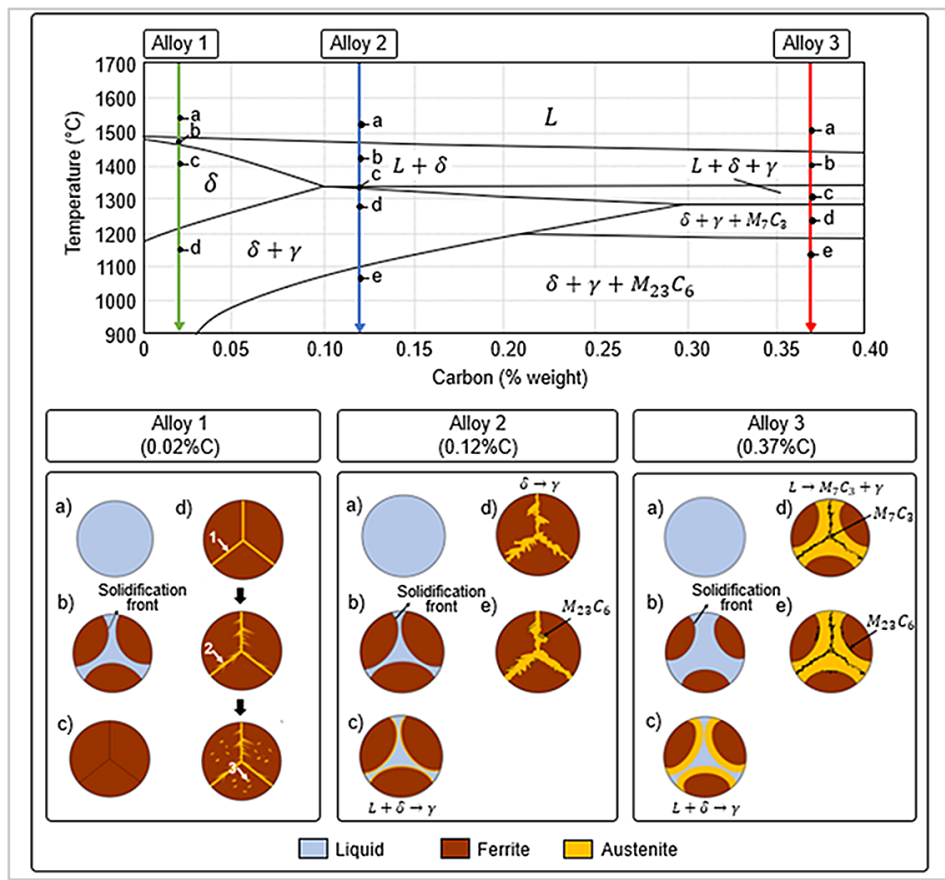

Figure 10 - Section of the mass-based Fe-25\%Cr-5\%Ni-0.80\%Mn-0.65\%Si-0.03\%N phase diagram and the schematic representations of alloys 1, 2, and 3 microstructure evolution.

It should be noted that the formation sequences represented in Fig. 10 considered only the phases observed in the characterization stage of alloys 1,2 , and 3. Considering the formation of all the other phases predicted in item 3.1, a fifth stage e) should be added to represent $\mathrm{M}_{23} \mathrm{C}_{6}$ carbide precipitation in alloy 1

\section{Conclusion}

Alloy 1, with 0.02 wt.\% , presented a solidification sequence $(L \rightarrow L+\delta \rightarrow \delta$ ) with austenite formed by solid-state precipitation $\left(\delta \rightarrow \gamma_{2}\right)$. and, for all alloys, a stage f) to represent the sigma phase precipitation. According to Ohmori and Maehara (1984), sigma phase precipitation begins on the new $\gamma / \delta$ boundaries formed after the growth of the $\mathrm{M}_{23} \mathrm{C}_{6} / \gamma_{3}$ eutectoid structure.

Finally, it is relevant to mention that the high carbon duplex stainless steels investigated herein are used in the as-cast condition, presenting nonequilibrium microstructures. On the other hand, the comparison of nonequilibrium microstructures with those provided by computational simulation for equilibrium conditions proved to be most helpful.
The $\mathrm{M}_{23} \mathrm{C}_{6}$ carbide was not observed in its microstructure. On the other hand, alloy 2, with $0.12 \mathrm{wt} . \% \mathrm{C}$, showed the solidification sequence $(L \rightarrow L+\delta \rightarrow \delta+\gamma)$ with austenite formed according to the peritectic reaction $(L+\delta \rightarrow \gamma)$. The presence of $\mathrm{M}_{23} \mathrm{C}_{6}$ carbides between ferrite and austenite was observed in its microstructure. 
Finally, alloy 3, with 0.37 wt.\% C, presented the solidification sequence $\left(L \rightarrow L+\delta \rightarrow \delta+\gamma+L \rightarrow \delta+\gamma+\mathrm{M}_{7} \mathrm{C}_{3}\right)$ with austenite formed through the peritectic

reaction $(L+\delta \rightarrow \gamma)$ and the $\mathrm{M}_{7} \mathrm{C}_{3}$ carbide according to the eutectic reaction $\left(L \rightarrow \gamma+M_{7} C_{3}\right)$. As solidification proceeds, the precipitation of $\mathrm{M}_{23} \mathrm{C}_{6}$ carbides is also possible. The presence of both carbides in the microstructure was verified by XRD.

\section{Acknowledgments}

One of the authors (E. M. A.) would like to thank Coordenação de Aperfeiçoamento de Pessoal de Nível
Superior - Brasil (CAPES) for the master scholarship granted (Process number 88887.343624/2019-00 - Finance Code
001). Thanks are due to Prof. Ronald Lesley Plaut for going through the manuscript meticulously.

\section{References}

AARONSON, H. I. The proeutectoid ferrite and the proeutectoid cementite reactions. In: ZACHAY, V. F.; AARONSON, H. I. Decomposition of austenite by diffusional processes. New York: Interscience Publishers, 1962. p. 387-546.

AMARAL, E. Estudo microestrutural de aços inoxidáveis dúplex Fe-25Cr-5Ni com teores de carbono entre 0,02\% e 0,37\% em massa. 2021. Dissertação (Mestrado em Ciências) - Escola Politécnica, Universidade de São Paulo, São Paulo, 2021.

ARNOLD, M. O. et al. Stahlguss: Herstellung-Eigenschaften Anwendung. Konstruieren und Gießen, v. 29, n. 1, p. 1-81, 2004.

DUBÉ C. A.; AARONSON, H. I.; MEHL, R. F. La formation de ferrite proeutectoïde dans les aciers au carbone. La Revue de Métallurgie. Paris, v. 55, n.3, p.201-210, 1958.

FU, J. W.; YANG, Y. S.; GUO, J. J; MA, J. C.; TONG, W. H. Formation of a two-phase microstructure in Fe-Cr-Ni alloy during directional solidification. Journal of Crystal Growth, v. 311, n. 1, p. 132-136, 2008.

GUNN, R. Duplex stainless steels: microstructure, properties and applications. Cambridge: Abington Publishing, 2003.

GUO, C. et al. Fatigue failure mechanism and life prediction of a cast duplex stainless steel after thermal aging. International Journal of Fatigue, v. 146, May 2021.

KLIAUGA, A. M. Microestrutura e resistência ao desgaste abrasivo de algumas ligas do sistema Fe-Cr-C. 1991. Dissertação (Mestrado em Engenharia Metalúrgica) - Escola Politécnica, Universidade de São Paulo, São Paulo, 1991.

KNYAZEVA, M.; POHL, M. Duplex steels. Part II: carbides and nitrides. Metallography, Microstructure, and Analysis, v. 2, n. 5, p. 343-351, 2013.

LI, S.; WANG, Y.; WANG, X. Influence of Mo additions on the mechanical properties of cast duplex stainless steels before and after thermal aging. Metals, v. 9, n. 3, p. 295, 2019.

OHMORI, Y.; MAEHARA, Y. Precipitation of $\mathrm{M}_{23} \mathrm{C}_{6}$ and $\sigma$-phase in $\delta / \gamma$ duplex stainless steels. Transactions of the Iron and Steel Institute of Japan, v. 24, n. 1, p. 60-68, 1984.

PADILHA, A. F.; RIOS, P. R. Decomposition of austenite in austenitic stainless steels. ISIJ International, v. 42, n. 4, p. 325-327, 2002.

PADILHA, A. F.; PLAUT, R. L. Phase transformation and microstructure. In: ALVAREZ-ARMAS, I.; DEGALLAIX-MOREUIL, S. (ed.). Duplex stainless steels. Hoboken, NJ: John Wiley \& Sons, 2013. p. 115-139.

POHL, M.; IBACH, A. Wear behavior of stainless steels used in the pump industry. In: CONGRESSO INTERNACIONAL DE TECNOLOGIA METALÚRGICA E DE MATERIAIS, 49., 1994, São Paulo. Proceedings [...]. São Paulo: ABM, 1994. v.8. p.415-429.

WIECZERZAK, K. et al. The effect of temperature on the evolution of eutectic carbides and $\mathrm{M}_{7} \mathrm{C}_{3} \rightarrow \mathrm{M}_{23} \mathrm{C}_{6}$ carbides reaction in the rapidly solidified Fe-Cr-C alloy. Journal of Alloys and Compounds, v. 698, p. 673-684, 2017.

Received: 1 March 2021 - Accepted: 7 July 2021. 